\title{
Support group: interpersonal relationships among puerpera with hospitalized newborn children*
}

\author{
Grupo de apoio: relações interpessoais entre puérperas com filhos recém-nascidos hospitalizados
}

Grupo de apoyo: relaciones interpersonales entre puérperas con hijos recién nacidos hospitalizados

\author{
Maria Adelane Alves Monteiro', Ana Karina Bezerra Pinheiro ${ }^{2}$, Ângela Maria \\ Alves e Souza ${ }^{3}$
}

\begin{abstract}
Objective To check interpersonal relationships among puerpera with hospitalized newborn children, experienced in the support group. Methods: Action research carried out at "Cara da Mamãe" (Mommy's Home), annexed to a philanthropic hospital in Sobral, Ceará State, in April 2005. The support group was formed by using, in the group approach, the theoretical construct proposed by Loomis. A preparatory and six group sessions were performed. Nine mothers participated in the study. Results: Both isolation and sadness of the new puerpera hinder other mothers approximation, influencing on the experience adaptation process. These mothers coping time is linked to the number of relationships established by them. The roles developed and the power of influence may be related to factors such as: educational background, age group and skills in providing support. Conclusion: The group approach may be used by nurses during intervention with mothers who accompany their hospitalized children. It may stimulate integration and support, favoring adaptation.
\end{abstract}

Keywords: Postnatal period; Group structure; Infant, newborn; Child, hospitalized; Mother-child relations

\section{RESUMO}

Objetivo: Verificar as relações interpessoais entre puérperas com filhos recém-nascidos hospitalizados vivenciadas no grupo de apoio/ suporte. Métodos: Pesquisa-ação realizada na "Casa da Mamãe", anexo de um hospital filantrópico de Sobral-CE, em abril de 2005. Formamos um grupo de apoio/suporte, utilizando como referencial teórico, na abordagem grupal, a proposta referida por Loomis. Realizamos uma sessão preparatória e seis sessões grupais. Participaram do estudo nove mães. Resultados: O isolamento e a tristeza da puérpera recémchegada dificulta a aproximação das outras mães, influenciando no processo de adaptação à experiência. O tempo de convivência dessas mães está ligado à qualidade das relações estabelecidas entre elas. Os papéis desenvolvidos e o poder de influência parecem estar relacionados a fatores como: nível de instrução, faixa etária e capacidade de oferecer apoio. Conclusão: A abordagem grupal pode ser utilizada pelos enfermeiros na intervenção junto a mães que acompanham os filhos hospitalizados, como forma de estimular a integração entre estas, buscando oferecimento de apoio/suporte e favorecendo a adaptação.

Descritores: Período pós-parto; Estrutura de grupo; Recém-nascido; Criança hospitalizada; Relações mãe-filho

\section{RESUMEN}

Objetivo: Verificar las relaciones interpersonales entre puérperas con hijos recién nacidos hospitalizados vivenciadas en el grupo de apoyo/ soporte. Métodos: Se trata de una investigación-acción realizada en la "Casa de la Mamá", anexo de un hospital filantrópico de Sobral-CE, en abril del 2005. Formamos un grupo de apoyo/soporte, utilizando como referencial teórico, en el abordaje grupal, la propuesta referida por Loomis. Realizamos una sesión preparatoria y seis sesiones grupales. Participaron en el estudio nueve madres. Resultados: El aislamiento y la tristeza de la puérpera recién llegada dificulta la aproximación de las madres, influenciando en el proceso de adaptación a la experiencia. El tiempo de convivencia de esas madres está ligado a la calidad de las relaciones establecidas entre ellas. Los papeles desarrollados y el poder de influencia parecen estar relacionados a factores como: nivel de instrucción, grupo etáreo y capacidad de ofrecer apoyo. Conclusión: El abordaje grupal puede ser utilizado por los enfermeros en la intervención con madres que acompañan a sus hijos hospitalizados, como forma de estimular la integración entre ellas, buscando ofrecimiento de apoyo/soporte y favoreciendo la adaptación.

Descriptores: Período de post parto; Estructura de grupo; Recién nacido; niño hospitalizado; Relaciones madre hijo

*Project performed at "Casa da Mamãe" (Mommy's Home), annexed to the philanthropic hospital in Sobral, (CE), Brazil.

${ }^{1}$ Master, Obstetrical Nursing Specialist at Universidade Estadual do Ceará UFCE- Fortaleza, (CE), Brazil.

${ }^{2}$ Ph.D., Professor at Universidade Estadual do Ceará UFCE - Fortaleza, (CE), Brazil.

${ }^{3}$ Ph.D., Professor at Universidade Estadual do Ceará UFCE - Fortaleza, CE, Brazil. 


\section{INTRODUCTION}

The Model Program of Mother-Child Care had the city of Sobral, in Ceará State, as one of the sites where it was developed. In this city, from 1998 to March 2004, there was a philanthropic hospital with secondary and tertiary reference. In 2001, this project implemented "Casa da Mamãe" ("Mommy's Home"), a place to host puerpera residing in other sites and whose newborn required hospitalization in the intermediate neonatal care. The institution did not have facilities for the mothers to accompany their children.

When the mothers are hosted in this site, they face the far-from-the-family situation, the hospitalizaed child and live through an important phase in the puerperal gravidity cicle which is puerperium. In this period, there are several anatomical and physiological bodily changes in the puerpera, impacting not only on the endocrinous and genital level, but overall. The woman, in this moment, should be regarded as a whole being, not disregarding her psychic component $t^{(1)}$. The hospitalization experience of a newborn child makes the puerperal period harder. These mothers, experiencing the absence of their children after term, trigger physical and emotional instability. They require nursing care to stimulate them positively in hardship, minimizing the more serious emotional problems and their repercussions in social and interpersonal life $\mathrm{f}^{(2)}$.

In "Mommy's Home", the puerpera endure together a new experience, which demands effort to adapt to the situation. The women react differently, establishing relationships which may impact, either positively or negatively, in this process. Therefore, practitioners who look after these people ought to use strategies that maximize strengths and minimize weaknesses among these relationships, which may affect the process of dealing and adjusting.

It is known that group work is a reality in nursing and it is experienced throughout academic education, bringing benefits, as it is a strategy for the professional nursing activity ${ }^{(3)}$. The group is also an instrument of great avail for the nurse to plan interventions, offering emotional care alternatives ${ }^{(4)}$. Regarding the care of mothers who accompany their hospitalized children, the groups constitute space for free speech and contribute to making them feel supported and valued. The group experience among people with similar problems may favor help relationships among the participants ${ }^{(5)}$.

Hence, the following objective was designed for this study: to check interpersonal relationships among puerpera with hospitalized newborn children, experienced in the support group.

\section{THEORETICAL FRAMEWORK}

As a guideline to develop this paper and as a theoretical background for the group approach, Loomis ${ }^{(6)}$, was used. He proposes group work developed by nurses, through an array of variables that may take place in the group setting, and are displayed in four interdependent descriptors: objectives, structure, process and group results ${ }^{(0)}$.

Before beginning group work, the aspects related to group stracturing should be observed such as: client selection, physical organization, time, group size, space and setting, as well as participant preparation. This may be performed in the preparatory session when there should be an approximation between nurse and people and when the rules and norms are defined while the group exists. This process is referred to as fundamental for the construction of the work contract or health care contract. It warns that participant and coordinator expectations should be considered and its evaluation and review should be constant whenever necessary ${ }^{()}$.

The types of groups available may be characterized according to the same variables. According to the objectives, the group can be: support, task performing, socialization, behavior changes learning, human relationships training and psychotherapy. The group structure itself may be used to define the type of group intended. They can be described and defined in relation to their inner process. The group formed for the research aimed primarily at providing emotional support and socialize the participants. The group aiming at providing support may aid people during change adjustment periods, crisis treatment or, even, maintainance or adaptation to the new situations ${ }^{(6)}$.

The following therapeutic factors may emerge out of a group therapy and provide a significant discussion basis and classification of health care group process: hope instillation, universality, information providing, altruism, corrective reedition of family primary group, development of socializing techniques, behavior imitation, interpersonal learning, group cohesion, catharsis and existential factors $^{(6)}$. They will show up as the participants begin to socialize and influence one another. Thus, during the group process, there will be situations that reflect the group member interaction, which comes from the development of roles and the pattern of power and influence of each participant, including the coordinator and the development of the group communication pattern during the session ${ }^{(6)}$. Some behavior- and attitude- related postures may be adopted, being part of the human relationships dynamics: change resistance, proximity, conflict situations and group problems resolutions. The coordinator role assumed in this phase is key for the group success due to the fact that the group cohesion relies on it. It may perform the function of emotional stimulation, caregiver, meaning attribution and executive ${ }^{(6)}$. 
Therefore, the group approach as referred by Loomis $^{(6)}$ may serve as theoretical and methodological frameworks for the study of the interpersonal relationships of puerperas living in a support house for hospitalized newborn children.

\section{METHODS}

This is a qualitative study, action research-like ${ }^{(7)}$ carried out in April 2005, in a support house named "Casa da Mamãe" (Mommy's Home), part of a philanthropic hospital in Sobral, Ceará State. This house harbors ten mothers and those staying there in this period to accompany the hospitalized children were invited to join the group, which would take place there, in the visit to the hospital interval. The mean newborn hospitalization time is 15 days. Thus, a preparatory session was planned and six group sessions, in consecutive days, seeking to avoid the entrance and exit of the group. Yet, it was an open group because three babies were discharged and others admitted. It eventually led to the entrance and exit of mothers in the group. Therefore, the exclusion criterion of the study was mothers who participated in at least three group sessions. Thus, nine mothers took part in the study. In order to maintain participant anonymity, names of birds were used as pseudonyms.

The group was led by the coordinator, responsible for the research, and two auxiliary coordinators, of the Undergraduate Nursing Course of Universidade Estadual Vale do Acaraú. They were supposed to observe the setting, verbal and non-verbal expression, and register key-happenings and information relevant to the field journal. There was also the aid of a recorder to register the participant speeches. The group objectives of providing support and socialization were established through previous interview with the mothers. A preestablished script was used and there was the investigation of factors concerning puerpera relationships. Their needs were identified in order to plan the sessions. Each session was divided into three moments: warming-up, focused on participant reception; development, in which art-therapy activities were performed and relaxing and finishing techniques, with previous and continuous evaluation of the group. The most used activities were: drawing, painting and collage.

The analyzed data were: group process observations; participant discourses; member willingness in each session, shown in configurations of communication patterns and registered pictures. The content collected was thoroughly respected, transcribed and analyzed, according to the theoretical construct adopted, when there was member interaction (role development, pattern of power and influence and pattern of communication). Also, the therapeutic factors emerged out of the group, with emphasis on the group cohesion ${ }^{(6)}$. Information collection and analysis took place simultaneously in order to evaluate the difficulties endured by the puerpera, as well as solving drawbacks that could occur when conducting the group.

Regarding the ethical procedures, the investigation respected the bioethical principles postulated by the Resolution n. ${ }^{\circ}$ 196/96 of the National Health Council/ Ministry of Health ${ }^{(8)}$, and the participants signed the consent form. This study project was approved by the Ethics and Research Committee of the Hospital Complex at Universidade Federal do Ceará, under authorization n. ${ }^{\circ}$ 183/05.

\section{RESULTS}

The results obtained allowed to characterize the study participants according to socioeconomic characteristics, described below, and afterwards, describe how the group sessions happened, with emphasis on the emerged content in the group process.

\section{Characterizing the study participants}

Four mothers were adolescents (age group between 10 and 19 years, according to the WHO). Maybe, also for this reason, every mother had dropped out school. Most of them had not completed elementary studies, and one had graduated from high school. This reality is directly related to the fact that half of the puerpera had family income lower than two minimum wages. Two had unemployed husbands. None earned more than two minimum wages. The puerpera woman, who managed to finish high school, was the only one who had a stable job. Regarding marital status, six mothers alleged to be married. However, those self-proclaimed "together", were actually living as singles, with their parents. Six mothers were originally from other cities, residing in the rural area, which made family visits difficult.

Four mothers were primiparas. Only one had been pregnant for the fourth time. The others were biparous. This reinforces how the experience of having a hospitalized newborn child was endured for the first time by these women. Only one had Cesarian section and the other study participants, vaginal delivery. Only one had the child in due time. The others gave birth prematurely. Therefore, prematurity was the main reason for hospitalization of children participating in this study.

\section{Describing the group sessions}

The sessions are described in this study, from observations of the communication pattern maintained during each session, the roles each group member performed and the curative factors ${ }^{(6)}$ emerged. These aspects are presented by means of configurations of 
the main sessions, constructed according to the theoretical construct adopted.

\section{Preparatory session}

The preparatory session may provide a coordinator initial relationship with the participants, afterwards transferred to the group. The result effectiveness of the group intervention also relies on the participant preparation for the start of the group ${ }^{(6)}$. Therefore, this session was performed with this orientation. The content of the preparatory session corresponded, basically to the definition of group functioning. The dialog and participative exposure technique was used ${ }^{(9)}$. The brainstorming technique ${ }^{(9)}$ was employed to raise the required points to build the Work Contract ${ }^{(6)}$ among the group members and coordinator. During the first meeting, she participated actively, even more than the group members, most of the time. Because she needed to clarify the whole research process and group work. There was not specific attention towards any members. Equal contact was maintained with all the participants.

'Thrush' mother and 'Cockatiel' mother remained silent for the entire session, however, they paid a lot of attention. They were likely to deal well with anxiety of the moment, remaining silent. Nevertheless, they were attentive to what was said. 'Macaw' mother was the only one who in some moments, showed herself distant. She seemed to want to express it. She complained that she was not "well" in the beginning of the session, but nobody gave feedback ${ }^{(6)}$. She did not seem to be enjoyed by the group. Maybe due to her insistence and fixation in getting her daughter discharged, and apparent depressive status. In this session, the participants decided not to talk about negative things. However, it was not possible to observe aspects of existing relationships that could denote some sort of conflict or positive bond among the mothers.

\section{Session I}

The emerged group content, during session 1 brought up more information, allowing to learn more about each group participant. There was a lot of altruism, experience of sharing yourself with others ${ }^{(6)}$. But little or no feedback ${ }^{(6)}$

LEGEND 1

1 'Humming bird' mother

2 'Great kiskadee' mother

3 'Macaw' mother

4 'Owl' mother

5 'Thrush' mother

6 'Gull' mother

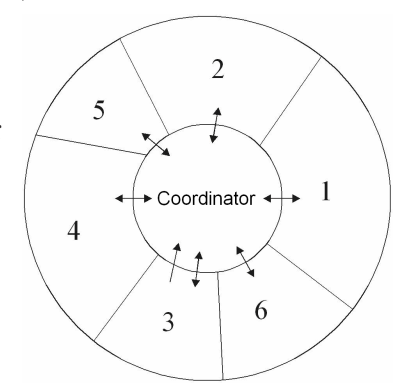

Figure 1- Group configuration in session 1
Through Figure 1, 'Humming bird' mother, 'Great kiskadee' mother and 'Owl' mother were the ones who talked the most. 'Thrush' mother and 'Macaw' mother would only listen without making comments, answering what was asked.

'Macaw' mother sat beside the coordinator and throughout the session she interacted more with her than with the other group participants. She was quite worried and sad. She did not have anyone close to whom she could count on the Home, expressing distance from the other mother. She started to play the role of an abandoned child and victim in the group. There was also some power and influence ${ }^{(6)}$ from 'Great kiskadee' mother in relation to the group, maybe because she had a greater educational background among them. When they were asked to decide, she was the fisrt to stand, giving her opinion and the others followed. Maybe the fact that 'Great kiskadee' mother had participated in the group previously, not related to health care, allowed her to have a better performance and willingness to aid the other members.

The moment the session was about to finish, there was hope instillation ${ }^{(6)}$, when they wish one another their children recover and point out the need of faith and hope. The fact that they were living through similar situations favors the maximization of positive aspects present in the puerpera relationships.

\section{Session II}

The content emerged during session II was related to what the participants enjoyed or not about themselves. Massage techniques and Free Drawing activities ${ }^{(9)}$ were used.

'Macaw' mother once again sat beside the coordinator, asking questions and making comments. Apparently, to get attention. 'Owl' mother still demonstrated some shyness and, sometimes, introspection moments. She demonstrated affection exchange and sharing with 'Humming bird' mother. 'Humming bird' mother, in turn, also demonstrated kinship with 'Great kiskadee' mother and seemed to be closer and closer. Proximity is the ability to contact yourself and others ${ }^{(6)}$. This is likely to happen due to the fact they had been at Home for longer. However, 'Thrush' mother and 'Macaw' mother who had the same mean stay, developed a restricted pattern of communication $^{(6)}$ during the session and little would they interact with the other group participants. 'Humming bird' mother seemed to want to extend communication towards everybody in the group, not only towards 'Great kiskadee' mother. There was interest in wanting to share experiences. This wish was already incipient in the previous session. During the whole session, the group showed good sense of humor, confirming the relaxed 
atmosphere, as referred by them.

The therapeutic factor that prevailed in this session was the catharsis, expression of feelings $\mathrm{s}^{(6)}$, when the mothers expressed their emotions in relation to the experience endured. Catharsis has great therapeutic value, it is one of the most observed phenomena in groups and it is only possible when there is group cohesion ${ }^{(6)}$. Thus, this fact may be considered as a sign that the relationships the mothers already showed were positive.

\section{Session III}

In session III, the Relationship $\mathrm{Web}^{(9)}$ technique was used so as to wake them for the importance of experiencing this in group. The Continue the Drawing activity $^{(9)}$ was also used. It consists of a single drawing with the participation of everybody.

As 'Thrush' mother demonstrated to be the shiest in the group, in this session, she was encouraged to talk more about herself. 'Macaw' mother, although she looked sad, talked more then the day before. In the moments the others laughed at funny sentences said by the group, she remained with her head down and did not laugh.

LEGEND 2
1 'Humming bird' mother
2 'Great kiskadee' mother
3 'Macaw' mother
4 'Owl' mother
5 'Thrush' mother
6 'Gull' mother
8 'Sparrow' mother
9 'Blackbird' mother

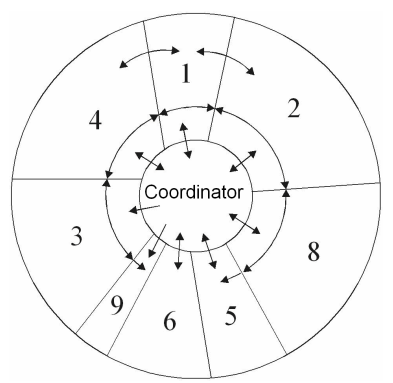

Figure 2-Group configuration in session III

According to this session configuration (Figure 2), the communication between 'Humming bird' mother and the other group participants was minimal in relation to the other sessions, due to the fact that she left in the middle of the session, because her baby had been discharged. All of them were interacting, however, the relationship of 'Humming bird' mother with 'Owl' mother and 'Great kiskadee' mother involved tenderness. There was a strong bond among them, even more evident when 'Humming bird' mother left. They promised to keep in touch after leaving the Home. 'Thrush' mother, although shy, would throw herself into the discussion, when she was talked to, and had a dialog with the others. She seemed to be starting to interact with the group. 'Sparrow' mother and 'Blackbird' mother were new to this session. The first showed good intention towards the group, even though it was her first meeting. The second had some mental deficiency. The other participants talked to her, but she was not able to give feedback ${ }^{(6)}$. Initially, the researchers were afraid of inviting 'Blackbird' mother to participate in the group, because of her deficiency and the reaction from the other participants. However, pretty soon all the mothers seemed to help her, explaining about the functioning of the Home and helping her with the group activities. Thus, in the first moment, this mother was considered by some members and even by the researcher as a group deviation, a problem to be solved. However, during the sessions, the positive way the puerpera sought to handle her, not excluding her out of the group, was clear

In the beginning of the study, the instability of the group members was considered to threaten the group cohesion $^{(6)}$, because it was an open group. However, the group itself had opted for this structure aspect, and even unconsciously the group solved naturally what could be a likely problem.

\section{Session IV}

In session IV, the Music and Movement technique ${ }^{(9)}$ was adopted and the mothers performed manual work activities. The Joy $\mathrm{Circle}^{(9)}$ technique was used to finish the activities and participants could verbalize their wishes, contributing to providing support among the group members. After 'Humming bird' mother and 'Great kiskadee' mother left, there was not any subgroup with strong bonds in the group setting. However, 'Sparrow' mother, 'Owl' mother and 'Macaw' mother seemed to be closer. The subgroup formation is an event that interferes in the group cohesion effectiveness because it sttimulates competion ${ }^{(6)}$. 'Sparrow' mother was the one who interacted with the group the most in this session. Although she was on her second day in the group, she interacted with everybody, except with 'Eagle' mother, who had arrived in the Home on that day and showed some hostility in relation to the other members. However, the other mothers insistedd, motivating her to take part in the group. The puerpera were always attempting to include 'Blackbird' mother in the discussions for her to feel a group member, but feedback was difficult. During the manual activity, 'Owl' mother, helping the mothers to manufacture the products, played the role of a group coordinator $^{(()}$.

\section{Session V}

In this session, also in other moments, information ${ }^{(())}$ was provided whenever the participants needed it.

In session V configuration, 'Macaw' mother seemed to want more attention and monopolized the conversation most of the time. The atmosphere was relaxed and this seemed to be what they wished. They wanted to get free from the negative feelings, although 'Macaw' mother insisted on her comments. When they 
LEGEND 3:

3 'Macaw' mother

4 'Owl' mother

8 'Sparrow' mother

9 'Blackbird' mother

10 'Macaw' mother

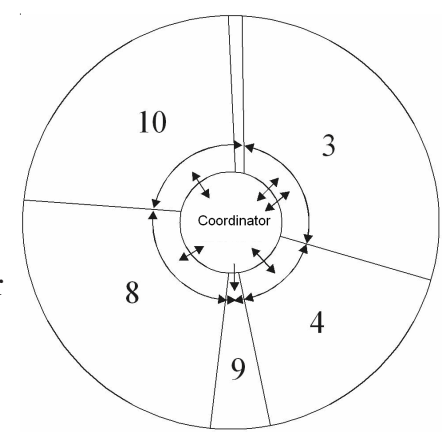

Figure 3-Group configuration in session V

referred to their children's health, this was done positively.

'Owl' mother, who was often talkative, only answered when questioned, made her point during the session. 'Eagle' mother was more receptive. She started to develop a pattern of power and influence ${ }^{()}$in the group. This power, however, was coercing ${ }^{(6)}$ and showed a critical posture regarding what happened in the group. Hence, the other group members feared her.

'Eagle' mother disagreed with everything 'Macaw' mother said. They would argue loudly. According to Figure 3, there is an interaction barrier between them, represented by the double line. The presence of opinions and diverging feelings may cause a conflict situation and in a group, the conflict may happen between two members, between subgroups and between the coordinator and members ${ }^{(6)}$. Nevertheless, despite de opinion divergence of 'Macaw' mother, 'Eagle' mother supported her when she talked about her daughter discharge. The group coordinator made them understand that it is possible to maintain their differences and receive one another's support. Thus, she performed her legitimate expert power in order to alter and favor roles and patterns of communnication ${ }^{(6)}$ established by the group members. The expert power may be possible when the nurse masters the group process subject and it is legitimate when the members recognize this power ${ }^{(()}$.

\section{Session VI}

The topic of having a having a hospitalized newborn child emerged more easily after the fourth session. They seemed not to enjoy talking about the topic. At the same time, they did not want to admit that they were sad. This topic was likely to be over-talked by them and the group allowed some space for them to share other life topics. This eventually made them closer as they got acquainted, favoring socialization and cohesion ${ }^{(6)}$, essential to reach the proposed objectives.

The group members showed to be clearly involved, even 'Blackbird' mother who did not talk. But her nonverbal expression was enough to show her enthusiasm for being part of the group. All of them attempted to talk for 'Blackbird' mother and had special attention towards her. However, 'Owl' mother demonstrated special affection and care towards her. 'Eagle' mother continued to diverge with 'Macaw' mother, but more constructively.

'Macaw' mother, who assumed the role of a lost child $^{(6)}$ in the group, managed with the aid of support, understand the process experienced by her. She stopped blaming someone for her daughter not having been discharged yet. The role of a child in the group was involuntarily assumed by 'Blackbird' mother.

'Owl' mother who only talked in the moment the activities were presented, in this session, participated more. She played the role of the group coordinator ${ }^{(6)}$, during the group drawing activity. 'Owl' mother, although seeming to be shy, in the last meetings started to share her feelings, revealed her power of reference influence ${ }^{()}$. Maybe because she was the oldest mother among the participants, being elected by the other members to coordinate the group. The reference power may be performed by the coordinator and/or other group members, depending on her interpersonal qualities $^{(0)}$.

The members regarded as influential or in a leading position, are often those who seek the group goals and facilitate the movement of other members to reach the objectives. Thus, the level and type of power and influence performed by the coordinator and the group members are related to the easiness of each person to help the group satisfy the objectives ${ }^{(\sigma)}$.

\section{DISCUSSION}

The formation of the support group for this study allowed relationships to be made evident, among women who are experiencing together the hospitalization of a newborn child, are filled with feelings and behaviors which may generate conflict among them. The Health Meeting Groups are designed for people experiencing common health-related problems. They are encouraged to report their feelings, fears, anxiety, seeking responses ${ }^{(10)}$. The support group proved to be an effective resource when used to deal with anxiety, fear and patient tension during hospitalization ${ }^{(11)}$.

The fact that they are in an unknown place, far from their family, makes them isolate in the first place. The sadness and apathy status, also shyness eventually hinder other mothers approximation, influencing on the adaptation process of the experience. Pessimism and lack of hope expressed by the puerpera are also factors that withdraw the possibility of interaction with the others.

Nevertheless, the newly arrived puerpera to the "Casa da Mamãe" may count on the support of mothers who 
are staying there. The group strategy was used aiming at stimulating socialization among them. The interpersonal relationships among the group ought to be filled with assistance.

The implementation of directed actions at the hospitalized children parents, through the formation of support groups may be evidenced in programs developed by nursing. They promote parent involvement to take care of the child, preparing them for the discharge ${ }^{(12)}$. However, when they start to accompany their hospitalized children, living in the same place, for a short time, the objectives of this type of group should be understood. The situation involves relationship questions.

These mothers coping time is linked to the number of relationships established by them. The roles developed and the power of influence among puerpera may be related to factors such as educational background, group age and skills in providing support. These skills should be maximized, in order to positively construct these relationships. The group setting constitutes a space that favors this action.

Through the group approach, the care may be performed holistically. Besides assisting the hospitalized baby, the parents receive the necessary attention. Thus, the group strategy may be worked out as a way to treat

\section{REFERENCES}

1. Brasil. Ministério da Saúde. Secretaria de Políticas de Saúde. Área Técnica de Saúde da Mulher. Parto, aborto e puerpério: assistência humanizada à mulher. Brasília: Ministério da Saúde; 2001.

2. Rocha RG, Handem PC, Silva ROL, Figueiredo NMA de. Imaginário das mães de filhos internados em UTIneonatal no pós-parto: contribuições para a enfermagem. Esc Anna Nery Rev Enferm. 2004; 8(2): 211-6.

3. Câmara MFB, Damásio VF, MunariDB. Vivenciando os desafios do trabalho em grupo. Revista Eletrônica de Enfermagem [Internet]. 1999; 1(1). [citado 2004 dez 1999]; Disponível: http:/ /www.fen.ufg.br/revista/revista1_1/09.htm

4. Munari DB, Ribeiro V, Lopes MM. Intervenção grupal com enfoque no cuidado emocional: relato de uma experiência. Rev Bras Enferm. 2002; 55(4): 449-51.

5. Campos ACS, Cardoso MVLL. Vivência da enfermeira junto a um grupo de mães com recém-nascidos internados. Rev RENE. 2002; 3(2):14-21.

6. Loomis ME. Group process for nurses. Saint Louis: the whole family, contributing to constructing a whole and humanized assistance ${ }^{(11)}$.

\section{CONCLUSIONS}

The research has reached its objective. The formation of the group in this study sought to evidence the interpersonal relationships among mothers who were experiencing their children hospitalization. The research intervened so as to facilitate their interaction.

The experience of a child hospitalization involves aspects that will generate behaviors and feelings that interfere in the adaptation of mothers to the new situation. The nurse should be careful regarding the relationships developed by the mothers accompanying their hospitalized children. Also, the roles and power of influence developed among them. The nurse should seek strategies that facilitate this relationships, maximizing positive aspects and minimizing the negative ones. Hence, the interpersonal relationship among the puerpera is filled with mutual help.

The group approach is a resource that may be used by nurses during intervention with mothers in order to stimulate their integration, seeking support and who favoring adaptation to the situation.

Mosby; 1979.

7. Thiollent M. Metodologia da pesquisa-ação. 13a ed. São Paulo: Cortez; 2004.

8. Brasil. Ministério da Saúde. Conselho Nacional de Saúde. Resolução n 196/96 sobre pesquisa envolvendo seres humanos. Brasília: Ministério da Saúde; 1996.

9. Liebmann M. Exercícios de arte para grupos: um manual de temas, jogos e exercícios. São Paulo: Summus; 2000.

10. Cardoso MVLL. O cuidado humanístico de enfermagem à mãe da criança com risco para alterações visuais: do neonato ao “toddler' [tese]. Fortaleza: Departamento de Enfermagem da Universidade Federal do Ceará; 2001.

11. Monteiro MAA, Pinheiro AKB, Leitão GCM. Análise do conceito de grupo como estratégia para o cuidado em enfermagem. Rev RENE. 2005; 9 (3):65-71.

12. Brunherotti MR, Pereira FL, Souza MI, Nogueira FS, Scochi CGS. Lazer para pais de bebês de risco: a experiência junto ao Hospital das Clínicas de Ribeirão Preto. Rev Bras Enferm. 2000; 53(3):435-42. 